has been reported in adults. ${ }^{6}$ NAG should be as useful in children as it is in adults for the detection of renal tubular disease, provided an accurate normal range is used.

I record with regret the death of Miss Susan Tucker whose research did much to advance this subject, and thank Professor Scopes, Dr McSwiney, and Mr A Thompson for assistance.

I am grateful for financial support from St Thomas's Hospital Research Endowment Fund.

\section{References}

1 Wellwood J M, Ellis B G, Price R G, Hammond K, Thompson A E, Jones N F. Urinary $N$-acetyl- $\beta-D-$ glucosaminidase activities in patients with renal disease. Br Med J 1975; iii : 408-11.

2 Tucker S M, Boyd P J R, Thompson A E, Price R G. Automated assay of $N$-acetyl- $\beta$-D-glucosaminidase in normal and pathological human urine. Clin Chim Acta 1975; 62: 333-9.

3 Kunin C M, Chesney R W, Craig W A, England A C, Deangelis C. Enzymuria as a marker of renal injury and disease. Studies of $N$-acetyl- $\beta$-glucosaminidase in the general population and in patients with renal disease. Pediatrics 1978; 62: 751-60.

4 Tucker S M. Studies of human $N$-acetyl- $\beta$-D-glucosaminidase with special reference to renal disease. $\mathrm{PhD}$ thesis, London University 1977.

5 Ellis B G, Tucker S M, Thompson A E, Price R G. Presence of serum and tissue forms of $N$-acetyl- $\beta$ glucosaminidase in urine from patients with renal disease. Clin Chim Acta 1975; 64: 195-202.

- Dieppe P A, Tucker S M, Burry H C, Bresnihan F P. The use of $\beta-N$-acetyl-glucosaminidase excretion to investigate renal disease in rheumatoid arthritis. Rheumatol Rehabil 1975; 14: 226-30.

7 Osborne J P. Urinary enzymes in the detection of renal damage in the newborn. MD thesis, London University 1980.

Correspondence to Dr John Osborne, Bristol Royal Hospital for Sick Children, St Michael's Hill, Bristol BS2 8BJ.

\title{
Maternal homocystinuria: studies of an untreated mother and fetus
}

\author{
T W KURCZYNSKI, W A MUIR, L D FLEISHER, J F PALOMAKI, G E GAULL, \\ D K RASSIN, AND C ABRAMOWSKY
}

\begin{abstract}
Department of Pediatrics, Department of Medicine, Department of Reproductive Biology, and Department of Pathology, Case Western Reserve University, Cleveland, Ohio, and Department of Human Development and Nutrition, New York State Institute for Basic Research in Mental Retardation, Staten Island, New York, USA
\end{abstract}

SUMMARY A 20-year-old woman with untreated homocystinuria was examined when she was 18 weeks' pregnant. Amniocentesis was performed and raised levels of homocystine and methionine were present in the amniotic fluid. Assay of cystathionine synthetase activity in cultured amniotic fluid cells showed the carrier state for homocystinuria. An abortion was performed because of the possible adverse effects of continuing the pregnancy both for the mother and the fetus. No pathological abnormality was found in the aborted fetus. Further data are needed to assess the possible teratogenic effects of maternal homocystinuria and the adverse consequences of pregnancy in the affected mother.

Homocystinuria comprises a group of autosomal recessive disorders of sulphur amino-acid metabolism. The most common type is due to a deficiency of cystathionine synthetase, a pyridoxal phosphatedependent enzyme which catalyses the reaction of serine with homocysteine to form cystathionine. This enzyme defect results in raised blood and urine levels of homocystine, methionine, and other sulphur amino-acids, and a lack of brain cystathionine. The clinical consequences vary and can include mental retardation, epilepsy, ectopia lentis, osteoporosis, skeletal anomalies (such as arachnodactyly and dolichostenomelia), fatty changes in the liver, and thrombotic vascular disease affecting any vessel in either the arterial or venous circulation. In many patients with cystathionine synthetase deficiency, treatment with pyridoxine appears to reverse the biochemical abnormalities and may prevent the development of manifestations of the disorder. ${ }^{1}$ An affected, pregnant woman who had stopped treatment provided a unique opportunity to evaluate the effects of maternal cystathionine synthetase deficiency on the developing fetus. 


\section{Case report}

A 20-year-old woman, 8 weeks' pregnant, was referred because of homocystinuria. She had been in good health until aged 12 years when she was tested for diminished visual acuity and found to have ectopia lentis bilaterally. At age 18 she began using birth control pills and after 6 months developed thrombophlebitis and suspected pulmonary emboli. Homocystinuria was diagnosed by increased blood and urine levels of homocystine and methionine. The birth control pills were stopped and she was treated with aspirin, folate, and pyridoxine. She stopped treatment on her own initiative after 6 months. There was no history in the patient or her family of mental retardation, seizures, skeletal anomalies, or any other vascular disease. When aged 3 years the patient's younger brother had been found to have ectopia lentis; he had initially been thought to have Marfan's syndrome. Now, at age 18, he has had no significant medical problem. One other sister died of a brain tumour. There is no parental consanguinity.

Both the patient and her brother were admitted to the Clinical Research Center of University Hospitals of Cleveland, Ohio for evaluation. General physical and neurological examinations were normal except for bilateral ectopia lentis, iridodonesis, and diminished visual acuity in both siblings and, in the patient, an enlarged uterus consistent with an 18-week pregnancy. The diagnosis of homocystinuria in both siblings was confirmed by quantitative plasma and urinary amino-acid analysis using an amino-acid analyser (Table). A skin biopsy was obtained from each of them for enzyme analysis. An amniocentesis was performed in order to measure the extent of increased amino-acids in the amniotic fluid, and to assay the relevant enzyme in cultured amniotic fluid cells. A control enzyme methylenetetrahydrofolate reductase was also assayed and found to be normal. Although total serum B12 and folate levels were normal, there was a decrease in the free folate level. There was no macrocytosis or anaemia and the significance of the low free folate is unclear. The data are presented in the Table. For emotional reasons and because there was the possibility of vascular complications during pregnancy as well as the risk to the fetus of untreated homocystinuria, the patient decided to undergo an abortion. Both she and her brother were subsequently treated with $500 \mathrm{mg}$ pyridoxine and $650 \mathrm{mg}$ aspirin daily, and plasma and urinary homocystine and methionine levels returned to normal.

Detailed light and ultrastructural pathological examination of the aborted fetus was performed and showed no abnormalities of the brain, other internal
Table Data on two siblings with homocystinuria

\begin{tabular}{|c|c|c|c|}
\hline & Patient & Brother & Normal \\
\hline \multicolumn{4}{|l|}{ Urine (per $\mathrm{g}$ creatinine) } \\
\hline Homocystine $(\mu \mathrm{mol})$ & 121 & $93 \cdot 3$ & 0 \\
\hline Methionine $(\mu \mathrm{mol})$ & 201 & 295 & $<12$ \\
\hline \multicolumn{4}{|l|}{ Plasma } \\
\hline Homocystine $(\mu \mathrm{mol} \%)$ & $0 \cdot 37$ & 1.49 & 0 \\
\hline \multicolumn{4}{|l|}{ Serum } \\
\hline Free folate $(\mathrm{ng} / \mathrm{ml})$ & 0.8 & 1.8 & $3-16$ \\
\hline Bound folate $(\mathrm{ng} / \mathrm{ml})$ & $5 \cdot 7$ & $5 \cdot 2$ & $0 \cdot 5-5$ \\
\hline $\mathrm{B} 12(\mathrm{pg} / \mathrm{ml})$ & 200 & 145 & $150-740$ \\
\hline \multicolumn{4}{|l|}{ Cultured skin fibroblasts } \\
\hline \multicolumn{4}{|c|}{ Enzyme activities (nmol/mg protein per hour) } \\
\hline $\begin{array}{l}\text { Cystathionine synthetase } \\
\text { (patient range }=0-3 \cdot 5 \text { ) }\end{array}$ & 0 & 0 & $9 \cdot 43-40 \cdot 0$ \\
\hline $\begin{array}{l}\text { Methylenetetrahydrofolate } \\
\text { reductase }\end{array}$ & $7 \cdot 55$ & $8 \cdot 56$ & $6 \cdot 70-12 \cdot 6$ \\
\hline \multicolumn{4}{|c|}{ Amniotic fluid at 18 weeks' gestation } \\
\hline Alpha-fetoprotein $(\mu \mathrm{g} / \mathrm{ml})$ & & & $1 \cdot 3-28$ \\
\hline Homocystine $(\mu \mathrm{mol} \%)$ & $2 \cdot 0$ & & $\mathbf{0}$ \\
\hline & 59 & & $1 \cdot 7-4 \cdot 1$ \\
\hline \multirow{2}{*}{\multicolumn{4}{|c|}{$\begin{array}{l}\text { Amniotic fluid cultured cells } \\
\text { Enzyme activities (nmol } / \mathrm{mg}\end{array}$}} \\
\hline & & & \\
\hline Cystathionine synthetase & 4.07 & & $27 \cdot 9-57 \cdot 6$ \\
\hline Methylenetetrahydrofolate & 4.07 & & $6 \cdot 20-19 \cdot 5$ \\
\hline
\end{tabular}

organs, or major blood vessels. The eyes were also normal, with no ectopia lentis or thickening of the basement membrane of the nonpigmented epithelium from the ciliary body.

\section{Discussion}

This is the first reported case of a pregnant woman with untreated homocystinuria. The fetus, although an obligate heterozygote for cystathionine synthetase deficiency, had been exposed to the biochemical environment of the homozygous recessive mother as shown by the presence in the amniotic fluid of homocystine, and a methionine level 15 to 30 times normal. ${ }^{2}$ In maternal phenylketonuria there can be severe congenital anomalies in an otherwise normal fetus-such as microcephaly and mental retardation. ${ }^{3-4}$ In this study no obvious pathological effects on the heterozygous fetus of about 18 weeks' gestational age were present; however, there were gross abnormalities in the free amino-acid pools in the fetal tissues. ${ }^{5}$ Bittle and Carson ${ }^{6}$ also reported a woman with cystathionine synthetase deficiency giving birth to an apparently normal heterozygous infant. Their patient had pyridoxine-responsive homocystinuria and so was treated throughout pregnancy. Pyridoxine had also been given during an earlier pregnancy which had terminated in a spontaneous abortion at 22 weeks. More data are needed in order to evaluate the risks of pregnancy in women with homocystinuria and to determine the long-term consequences on the infants born to such women. 


\section{References}

1 Gaull G E, Rassin D K, Struman J A. Letter: Pyridoxine dependency in homocystinuria. Lancet 1968; ii: 1302.

2 Reid D W J, Campbell D J, Yakymyshyn I Y. Quantitative amino acids in amniotic fluid and maternal plasma in early and late pregnancy. Am J Obstet Gynecol 1971 ; 111 : 251-8.

3 Mabry C C, Denniston J C, Coldwell J F. Mental retardation in children of phenylketonuric mothers. $N$ Engl J Med 1966; 275: 1331-6.

4 Stevenson R E, Huntley C C. Congenital malformations in offspring of phenylketonuric mothers. Pediatrics 1967; 40: $33-45$.
5 Rassin D K, Fleisher L D, Muir A, Desnick R J, Gaull $\mathrm{G}$ E. Fetal tissue amino acid concentrations in argininesuccinic aciduria and in maternal homocystinuria. Clin Chim Acta 1979; 94: 101-8.

- Bittle A H, Carson N A J. Tissue culture techniques as an aid to prenatal diagnosis and genetic counselling in homocystinuria. J Med Genet 1973; 10: 120-1.

Correspondence to Dr T W Kurczynski, Department of Pediatrics, Case Western Reserve University, Cleveland, Ohio 44106, USA.

\title{
Asymptomatic bacteriuria in healthy preterm babies
}

\author{
M MONCRIEFF, M BAMFORD, J BENSON, AND JANE BODDEN
}

John Radcliffe Hospital, Oxford

SUMMARY Urine was cultured from 151 healthy preterm babies. If the initial bag specimen grew more than 50000 organisms $/ \mathrm{ml}$, a second bag specimen was cultured. After two positive bag specimens a suprapubicurine wascultured. Significant bacteriuria was excluded on the basis of one or two bag specimens in $90 \%$ of the babies. Suprapubic urine was sterile in a further 11 babies. Four babies with positive bag specimens were unfortunately not completely investigated: 2 had mixed growths and 2 had pure growths of 100000 organisms/ml. As we and others consider that bacteriuria can only be diagnosed on a suprapubic sample of urine the incidence of proved infection in our series was zero. If both the babies with a pure growth of 100000 organisms $/ \mathrm{ml}$ had true bacteriuria, the incidence would rise to $1 \cdot 3 \%$. In view of the difficulties in obtaining clean urine samples in preterm babies and as the incidence of bacteriuria is so low, we do not recommend that healthy preterm babies be screened for bacteriuria.

Numerous surveys have shown that between 1 and $2 \%$ of girls have asymptomatic bacteriuria, and many already have renal scars present at the time of diagnosis. This applies to schoolchildren, ${ }^{1}$ school entrants, ${ }^{2}$ and to younger children and infants after the newborn period. ${ }^{3}$ It is likely therefore that asymptomatic bacteriuria occurs in the newborn period in at least some of these children, and treatment then might prevent the subsequent development of renal damage. However, Edelman et al. $^{4}$ found no clear case of asymptomatic bacteriuria in 836 healthy term newborn babies, although in preterm babies, who are particularly liable to infection, an appreciable incidence has been reported, varying from $2 \cdot 4^{4}$ to $25 \%{ }^{5}$ In view of this large difference in incidence we, too, carried out a survey to detect asymptomatic bacteriuria in preterm babies, and we assess the usefulness of such screening.

\section{Methods}

Urine was collected from babies of less than 37 weeks' gestation, who were not acutely ill, and who were not receiving antibiotics. Gestation was estimated from the beginning of the mother's last menstrual period, and confirmed by the modified Farr score. ${ }^{6}$

The baby's genitalia were washed with tap water, dried with a sterile cotton-wool swab, and a urine collecting bag was applied. The bag was inspected every 15 minutes. As soon as urine was passed it was transferred to a sterile bottle and taken to the laboratory. Most samples were examined immediately, but some were refrigerated overnight and examined the next morning. A standard calibrated loop, which delivers $2 \mu \mathrm{l}$, was used to inoculate blood agar and MacConkey's agar. The colonies were counted after overnight incubation.

Initially we planned that if the first urine contained $>10000$ organisms $/ \mathrm{ml}$ a second bag specimen would be cultured a few days later. If two bag specimens grew $>10000$ organisms $/ \mathrm{ml}$ a third specimen would be obtained soon afterwards by suprapubic bladder puncture (SP urine). However 18 of the first 30 bag 